\title{
The clinical impacts of early using glutamine/arginine enriched high protein density formula at trophic dose in intolerant enteral nutrition cachectic hypoalbuminemic hospitalized patients
}

\author{
HUSSIEN AL-SHEBLI ${ }^{1}$, SAMEER AL-SHAYYAB 1 , "MOH'D NOUR" BANI YOUNES ${ }^{2}$, SINAN BADWAN ${ }^{3}$, \\ MOHAMMED OBEIDAT ${ }^{4}$, AMANI ALSHAWABKEH $^{5}$, AREEJ ALMANASEER ${ }^{5}$, RAZAN FANNOUN $^{5}$ \\ ${ }^{1}$ Jordanian Royal Medical Services, Internal medicine/Nephrologist, Amman-Jordan \\ ${ }^{2}$ Jordanian Royal Medical Services, Adult Critical Care Unit, Amman-Jordan \\ ${ }^{3}$ Jordanian Royal Medical Services, Internal medicine/Oncologist, Amman-Jordan \\ ${ }^{4}$ Jordanian Royal Medical Services, Internal Medicine/Infectious Disease, Amman-Jordan \\ ${ }^{5}$ Jordanian Royal Medical Services, Clinical pharmacy, Amman-Jordan
}

\begin{abstract}
Background. We sought to evaluate the clinical impacts of the early administration of trophic doses of a glutamine/arginine enriched enteral nutrition formula (ENF) with a high protein density to cachectic hypoalbuminemic hospitalized patients intolerant to enteral nutrition.

Methods. A retrospective analysis was conducted using the nutritional and non-nutritional data of patients admitted to our institution from April 2017 through August 2019. Patients who died or were discharged before completing $\geq 1$ weeks of hospital admission, or those whose data could not be obtained were excluded. Among other variables, percent changes in serum albumin levels $(\% \triangle \mathrm{ALB}), \mathrm{C}-$ reactive protein (CRP) and their ratios were expressed as Mean $\pm \mathrm{SD}$ using the Independent Samples T-test, while categorical variables were expressed as numbers with percentages by using $\chi^{2}$ test. Two tested groups were determined based on the use of ENF: Group I received trophic doses of ENF, while Group II received no enteral nutrition.

Results. The overall hospital length of stay (LOS) and overall 28-day hospital mortality were significantly lower in Group I when compared with Group II with Means \pm SDs of $(11.32 \pm 2.19$ days vs $23.49 \pm 4.33$ days) and ( $13.13 \%$ vs. $28.16 \%$ ), respectively. Also, significantly higher $(\% \Delta \mathrm{ALB})$ for Group I compared with group II $(43.48 \% \pm 7.89 \%$ vs. $33.45 \% \pm 6.18 \%)$, respectively was observed.

Conclusion. In malnourished hypoalbuminemic patients suffering from feeding intolerance, early trophic administration of glutamine/arginine enriched high protein density ENF was well tolerated and may be associated with increased plasma albumin levels, reduced LOS, and overall 28-day mortality, and hence may be considered in such patients.
\end{abstract}

Key words: enteral nutritional formulas, high protein density, enterocyte nutrients, trophic feeding.

\section{Clinical relevancy statement}

The major clinical outcomes of overall length of stay days and mortalities may be improved by early initiation of high protein density formulas that were enriched by conditionally-essential immuneenhancing amino acids of glutamine and arginine. Then results of our study may force the care of severe malnourished critically ill patients and assist in the course of effective treatment.

\section{INTRODUCTION}

Feeding intolerance (FI) is commonly encountered in hospitalized patients and has been associated with poor clinical outcomes [1]. The provision of adequate alimentation is most commonly hindered by FI especially in critically ill patients $[2,3]$. FI is most commonly defined as gastric residual volume $(\mathrm{GRV})>150 \mathrm{ml}$, along with additional gastrointestinal (GI) symptoms [4]. FI prevalence in hospitalized patients is widely variable with approximately of $1 / 3$ in whom receiving enteral nutritional formulas (ENFs) and it is reported as a predictor of mortality which mandates both early and appropriately management [5-9].

The ASPEN, ESPEN, SCCM, and other guidelines on clinical nutrition recommend the early use of enteral nutrition (EN) over parenteral nutrition $(\mathrm{PN})$, when possible, for hospitalized malnourished patients who require nutritional support [10-11]. The premise of this recommendation is that EN reduces infectious morbidity (e.g. PN-associated central line infections and GI associated sepsis) and most other major clinical outcomes [12]. EN, especially in early stage, sustains an intact enteric mucosal barrier by supporting its structural, functional, and immunological elements and prevents dyspiosis which ultimately impedes bacterial translocation 
and sepsis [13-19]. Intestinal starvation, with or without PN, has been shown to dramatically increase mucosal permeability and impair mucosal defenses in both animal and human models [20].

EN sustains gut barrier integrity. Structurally, EN maintains mucosal mass by stimulating enterocyte proliferation, preserving villus height, and stimulating the physiologic production of brush border enzymes [17-19]. EN prevents dysbiosis and stimulates secretory immunoglobulin A production, tight junction synthesis and mesenteric blood flow, which results in higher and more efficient mucosal functionality [17]. Early administering $\mathrm{EN}$ at $\mathrm{TF}$ rate of $10-20 \mathrm{~mL} / \mathrm{h}$ was found to be sufficient in achieving most of aforementioned positive clinical impacts with less FI when compared with partial or full-energy EF [21-23].

Enterocytes are primarily fed on two major nutrients; short chain fatty acids (SCFAs) and glutamine. SCFAs are the end active metabolite of bacterial fermentation for non-digestible, nonabsorbable, but fermentable soluble fibers. These SCFAs production are largely dependent on probiotic fermentation step which is significantly affected by broad spectrum antibiotics that are commonly used in hospitalized patients [24-28]. The "conditionally essential' amino acids (cAAs), glutamine and arginine, have been shown to be effective in the setting of an accelerated catabolism that causes an increase in the cellular consumption of glutamine (the main source of energy for rapidly proliferating cells such as enterocytes, colonocytes, and lymphocytes and the most important enterocyte-nutrient which is directly utilized independent on bacterial fermentation processes) and arginine (An immune-enhancing cAAs in addition to glutamine) [29-34].

ArgiMent ${ }^{\circledR}$ is a new specialized ready to mix (RTM) modular formula (MF) available in our institution and is recently introduced in our nutritional formulary list. When one sachet of ArgiMent ${ }^{\circledR}$ $(42.75 \mathrm{~g})$ reconstituted with $120 \mathrm{ml}$ water is yielded approximately a moderate caloric density of $1.2 \mathrm{Cal} / \mathrm{ml}$ and very high protein density of $15 \mathrm{~g} / 100 \mathrm{Cal}(\approx 30 \%$ from glutamine, $\approx 30 \%$ from arginine, and $\approx 40 \%$ from whey protein) in addition to other Immunoenhancing and wound healing nutrients of vit $\mathrm{C}$, Zinc, and Cupper. Hence, a glutamine/arginine enriched ENF was used in our cohort who would otherwise remain NPO due to FI. We hypothesized that the early administration of $10 \mathrm{ml}$ of glutamine/arginine enriched ENF would attenuate albumin and overall protein catabolism, maintain GI integrity and impeding bacterial translocation, and consequently, improve positive major clinical outcomes of interest.

\section{MATERIAL AND METHODS}

We conducted an observational retrospective study at the King Hussein Medical Center (KHMC) of the Royal Medical Services (RMS) in Amman, Jordan. Institutional Review Board (IRB) approval was obtained. Nutritional and non-nutritional data of patients admitted to KHMC from April 2017 through Aug 2019 were collected via our electronic health record $\left(\right.$ Hakeem $\left.^{\mathbb{B}}\right)$. Inclusion criteria comprised of adult, moderate-severe malnourished patients based on subjective global assessment (SGA) who were intolerant to ENFs regardless of the reason for admission. Exclusion criteria comprised of patients who died or were discharged before completing at least one week of hospital admission, and those whose data could not be obtained. Intolerance to ENF in this study was defined as: A GRV exceeding $150 \mathrm{~mL}$ before ENF intake; a GRV that persisted above $150 \mathrm{~mL}$ after ENF intake despite the administration of prokinetic (metoclopramide 5-10 mg IV or erythromycin $250 \mathrm{mg}$ Suspension); or intolerable abdominal distention, abdominal cramping, or diarrhea. Patients were divided into a glutamine-arginine enriched ENF group (Group I) and a control group (Group II). The ENF was administered in trophic doses over the course of 16 hours daily for at least 3 days; rates were started at $5 \mathrm{~mL} / \mathrm{hr}$ and titrated, as tolerated, up to a of maximum $20 \mathrm{~mL} / \mathrm{hr}$. Our available ENF that met the aforementioned criteria (ArgiMent $\left.{ }^{\circledR}\right)$ was used within 3 hours after reconstitution with $120 \mathrm{ml}$ water due to glutamine stability concern. The control, Group II, received no enteral feeding. Primary endpoints were patients' overall 28-day mortality and hospital LOS. Secondary endpoints included patients' signs of GI intolerance, changes in GRVs before and after ENF administration, requirements for prokinetics, fistula and overall fluid outputs, hemodynamic parameters, respiratory quotients, changes in Sequential Organ Failure Assessment (SOFA) scores, and blood chemistries of CRP, ALB, and BUN. Quantifiable variables were expressed as Mean $\pm \mathrm{SD}$ and used the independent samples t-test for analysis, while categorical variables were expressed as percentage (number) and used chi-squared test for analysis. Values were compared for the two tested groups. We conducted all statistical analyses using IBM SPSS v. 25 (IBM Corp., Armonk, NY, USA) and considered $\mathrm{P}$-values $\leq 0.05$ as statistically significant.

\section{RESULTS}

Our total study population was 202 adults; $69.8 \%$ were males and $30.2 \%$ were females. The age of the total sample was $59.05 \pm 10.74$ years. 
Group I had significantly reduced mortality compared with Group II (13.13\% vs. $28.16 \%)$, respectively. The overall hospital LOS was also significantly shorter in Group I with $11.32 \pm 2.19$ days vs $23.49 \pm 4.33$ days for Group II. There were no significant differences in age, body mass index (BMI), body weight (BW), total daily caloric intake (TCI), or fluid outputs ( FLUD) between the two tested groups. At baseline, patients in Group I demonstrated significantly lower plasma albumin levels $\left(\mathrm{ALB}_{1}\right)$ than Group II $(2.27 \pm 0.15 \mathrm{~g} / \mathrm{dl}$ vs. $2.47 \pm 0.13 \mathrm{~g} / \mathrm{dl})$, respectively. While the plasma albumin levels after receiving trophic doses of ENF $\left(\mathrm{ALB}_{2}\right)$ in Group I increased to $3.25 \pm 0.06 \mathrm{~g} / \mathrm{dl}, \mathrm{ALB}_{2}$ in Group II was also increased to $3.29 \pm 0.02 \mathrm{~g} / \mathrm{dl}$ in Group II, since they received no enteral feeding: yielding significantly higher percent changes in albumin levels (\% $\%$ ALB) for Group I compared with Group II $(43.48 \% \pm 7.89 \%$ vs. $33.45 \% \pm 6.18 \%)$, respectively. Higher $\% \triangle A L B$ was associated with significantly lower IV human albumin intake (H.ALB) and significantly lower percent changes of blood urea nitrogen $(\% \Delta \mathrm{BUN}) \quad(19.69 \pm 1.72 \mathrm{~g} /$ day vs $21.17 \pm 3.51 \mathrm{~g} /$ day $)$ and $(26.29 \% \pm 44.16 \%$ vs $29.83 \% \pm 49.41 \%$ ), for Group I vs. Group II, respectively. The albumin levels are to be considered despite the significantly higher CRP levels in Group I at all stages with $\% \triangle$ CRP:ALB ratio of $95.27 \% \pm 35.49 \%$ for Group I vs. $74.68 \% \pm 22.08 \%$ for Group II. Concerning gastrointestinal (GI) symptoms, there were no significant differences in the incidence of GI symptoms; measured as the occurrence of $\geq 2$ symptoms (e.g. bloating, cramping, elevated GRV, or dyspepsia). Hemodynamically, no significant differences were measured in systolic blood pressure (SBP), diastolic blood pressure (DPB), mean arterial pressure (MAP), heart rate (HR), or shock index (SI). However, modified shock index (mSI) and norepinephrine (NE) requirements were significantly higher in Group II $(1.41 \pm 0.33 \mathrm{bpm} / \mathrm{mmHg}$ vs. $1.68 \pm 0.51 . \mathrm{bpm} / \mathrm{mmHg})$ and $(5.86 \pm 5.63 \mu \mathrm{g} / \mathrm{min}$ vs. $7.42 \pm 7.01 \mu \mathrm{g} / \mathrm{min}$ ) for (Group I vs. Group II), respectively. Pertaining to glycemic control, Group II exhibited significantly higher average serum glucose readings $\left(\mathrm{BG}_{\mathrm{avg}}\right)$ than Group I $(185.2 \pm 3.61 \mathrm{mg} / \mathrm{dL}$ vs. $192.3 \pm 6.80 \mathrm{mg} / \mathrm{dL}$ ) with a subsequently higher total daily insulin (TDI) dose $(27.25 \pm 6.14 \mathrm{IU} /$ day vs. $43.62 \pm 15.97 \mathrm{IU} /$ day) yielding higher serum glucose variability $\left(\% \mathrm{BG}_{\mathrm{var}}\right) 44.14 \% \pm 11.49 \%$ in Group I and $56.11 \% \pm 19.19 \%$ in Group II. Although there were insignificant differences in GRVs between the tested groups, the percentage of patients who received prokinetics was significantly lower in Group I 12.1\% when compared with Group II $35.9 \%$. Patients in Group I had significantly lower $\mathrm{PaCO}_{2}(37.90 \pm 0.77 \mathrm{mmHg}$ vs. $51.92 \pm 9.85 \mathrm{mmHg})$ and a significantly higher $\mathrm{PaO}_{2}(72.92 \pm 0.84 \mathrm{mmHg}$ vs. $50.52 \pm 10.46 \mathrm{mmHg}$ ) than Group II, respectively. Demographics, anthropometrics, nutritional indices, and follow-up comparison data of the study's malnourished hypoalbuminemic hospitalized patients are summarised in Tables 1-2.

Table 1

Baseline and follow-up categorical data of the comparative studied malnourished patient

\begin{tabular}{|c|c|c|c|c|c|}
\hline \multicolumn{2}{|c|}{ Variables } & \multirow{2}{*}{$\begin{array}{c}\begin{array}{c}\text { Total } \\
(\mathbf{N}=\mathbf{2 0 2})\end{array} \\
61(30.2 \%)\end{array}$} & \multirow{2}{*}{$\begin{array}{c}\begin{array}{c}\text { Group I } \\
\text { (N = 99) }\end{array} \\
29(29.3 \%)\end{array}$} & \multirow{2}{*}{$\begin{array}{c}\begin{array}{c}\text { Group II } \\
\text { (N = 103) }\end{array} \\
32(31.1 \%)\end{array}$} & \multirow{3}{*}{$\begin{array}{c}\text { P-value } \\
0.452 \text { (NS) }\end{array}$} \\
\hline \multirow{2}{*}{ Sex } & Female & & & & \\
\hline & Male & $141(69.8 \%)$ & $70(70.7 \%)$ & $71(68.9 \%)$ & \\
\hline \multirow{2}{*}{ Ward } & Non-Critical care & $94(46.53 \%)$ & $46(46.46 \%)$ & $48(46.60 \%)$ & \multirow{2}{*}{$0.312(\mathrm{NS})$} \\
\hline & Critical care & $108(53.46 \%)$ & $53(53.53 \%)$ & $55(53.39 \%)$ & \\
\hline \multirow{2}{*}{ Medical Dx } & Medical & $88(43.56 \%)$ & $43(43.43 \%)$ & $45(43.69 \%)$ & \multirow{2}{*}{$0.556(\mathrm{NS})$} \\
\hline & Surgical & $114(56.44 \%)$ & $56(56.57 \%)$ & $58(56.31 \%)$ & \\
\hline \multirow{2}{*}{ SGA } & Moderate wasting & $93(46.04 \%)$ & $44(44.44 \%)$ & $49(47.57 \%)$ & \multirow{2}{*}{$0.412(\mathrm{NS})$} \\
\hline & Severe wasting & $109(53.96 \%)$ & $55(55.55 \%)$ & $54(52.43 \%)$ & \\
\hline \multirow{2}{*}{$\begin{array}{l}\text { Prokinetic } \\
\text { administration }\end{array}$} & No & $153(75.7 \%)$ & $87(87.9 \%)$ & $66(64.1 \%)$ & \multirow{2}{*}{$0.000(\mathrm{~S})$} \\
\hline & Yes & $49(24.3 \%)$ & $12(12.1 \%)$ & $37(35.9 \%)$ & \\
\hline \multirow{2}{*}{ GI Sx } & $<2$ & $173(85.6 \%)$ & $87(87.9 \%)$ & $86(83.5 \%)$ & \multirow{2}{*}{$0.246(\mathrm{NS})$} \\
\hline & $\geq 2$ & $29(14.4 \%)$ & $12(12.1 \%)$ & $17(16.5 \%)$ & \\
\hline \multirow{2}{*}{$\triangle \mathrm{SOFA}$} & $<2$ & $135(66.83 \%)$ & $74(74.75 \%)$ & $61(59.22 \%)$ & \multirow{2}{*}{$0.031(\mathrm{~S})$} \\
\hline & $\geq 2$ & $67(33.17 \%)$ & $25(25.25 \%)$ & $42(40.78 \%)$ & \\
\hline \multirow{2}{*}{$\begin{array}{l}\text { Overall 28-day } \\
\text { Mortality }\end{array}$} & No & $160(79.21 \%)$ & $86(86.87 \%)$ & $74(71.84 \%)$ & \multirow{2}{*}{$0.001(\mathrm{~S})$} \\
\hline & Yes & $42(20.79 \%)$ & $13(13.13 \%)$ & $29(28.16 \%)$ & \\
\hline \multicolumn{6}{|c|}{$\begin{array}{l}\text { Data are presented as number (\%) using Chi-square test } \\
\text { Group I: Moderate-severe malnourished hospitalized patients used trophic feeding strategy. } \\
\text { Group II: Moderate-severe malnourished hospitalized patients used nothing by mouth strategy. }\end{array}$} \\
\hline
\end{tabular}


Table 2

Baseline and follow-up non-categorical data of the comparative studied malnourished patient

\begin{tabular}{|c|c|c|c|c|}
\hline Variables & $\begin{array}{c}\text { Total } \\
(\mathbf{N}=\mathbf{2 0 2}) \\
\end{array}$ & $\begin{array}{l}\text { Group I } \\
(\mathbf{N}=99) \\
\end{array}$ & $\begin{array}{l}\text { Group II } \\
(\mathbf{N}=103) \\
\end{array}$ & P-value \\
\hline Age (Yrs.) & $59.05 \pm 10.74$ & $58.81 \pm 10.22$ & $59.29 \pm 11.27$ & $0.381(\mathrm{NS})$ \\
\hline $\mathrm{BW}(\mathrm{Kg})$ & $73.97 \pm 10.23$ & $74.96 \pm 10.08$ & $73.02 \pm 10.32$ & $0.178(\mathrm{NS})$ \\
\hline $\operatorname{BMI}\left(\mathrm{Kg} / \mathrm{m}^{2}\right)$ & $25.86 \pm 3.98$ & $26.43 \pm 3.93$ & $25.31 \pm 3.96$ & $0.572(\mathrm{NS})$ \\
\hline $\mathrm{CRP}_{1}(\mathrm{mg} / \mathrm{dl})$ & $13.25 \pm 4.19$ & $15.40 \pm 4.54$ & $11.01 \pm 2.14$ & $0.000(\mathrm{~S})$ \\
\hline $\mathrm{ALB}_{1}(\mathrm{~g} / \mathrm{dl})$ & $2.37 \pm 0.17$ & $2.27 \pm 0.15$ & $2.47 \pm 0.13$ & $0.043(\mathrm{~S})$ \\
\hline $\mathrm{CRP}_{1}: \mathrm{ALB}_{1}$ & $5.75 \pm 2.40$ & $6.95 \pm 2.69$ & $4.51 \pm 1.11$ & $0.000(\mathrm{~S})$ \\
\hline H.ALB (g/day) & $20.45 \pm 2.87$ & $19.69 \pm 1.72$ & $21.17 \pm 3.51$ & $0.000(\mathrm{~S})$ \\
\hline $\mathrm{CRP}_{2}(\mathrm{mg} / \mathrm{dl})$ & $34.11 \pm 13.37$ & $42.38 \pm 13.72$ & $25.49 \pm 4.88$ & $0.000(\mathrm{~S})$ \\
\hline $\mathrm{ALB}_{2}(\mathrm{~g} / \mathrm{dl})$ & $3.27 \pm 0.05$ & $3.25 \pm 0.06$ & $3.29 \pm 0.02$ & $0.000(\mathrm{~S})$ \\
\hline $\mathrm{CRP}_{2}: \mathrm{ALB}_{2}$ & $10.49 \pm 4.41$ & $13.12 \pm 4.68$ & $7.76 \pm 1.51$ & $0.000(\mathrm{~S})$ \\
\hline$\% \Delta$ ALB & $38.57 \% \pm 8.68 \%$ & $43.48 \% \pm 7.89 \%$ & $33.45 \% \pm 6.18 \%$ & $0.005(\mathrm{~S})$ \\
\hline$\% \Delta \mathrm{CRP}$ & $155.8 \% \pm 40.85 \%$ & $178.2 \% \pm 40.04 \%$ & $132.5 \% \pm 26.08 \%$ & $0.000(\mathrm{~S})$ \\
\hline$\% \Delta$ CRP:ALB ratio & $85.18 \% \pm 31.37 \%$ & $95.27 \% \pm 35.49 \%$ & $74.68 \% \pm 22.08 \%$ & $0.000(\mathrm{~S})$ \\
\hline $\mathrm{BUN}_{1}(\mathrm{mg} / \mathrm{dl})$ & $15.06 \pm 5.28$ & $12.59 \pm 3.98$ & $17.44 \pm 5.31$ & $0.002(\mathrm{~S})$ \\
\hline $\mathrm{BUN}_{2}(\mathrm{mg} / \mathrm{dl})$ & $17.60 \pm 4.11$ & $14.63 \pm 2.37$ & $20.46 \pm 3.32$ & $0.018(\mathrm{~S})$ \\
\hline$\% \Delta \mathrm{BUN}$ & $28.09 \% \pm 46.83 \%$ & $26.29 \% \pm 44.16 \%$ & $29.83 \% \pm 49.41 \%$ & $0.271(\mathrm{NS})$ \\
\hline TCI (Cal/kg/day) & $9.48 \pm 0.69$ & $9.88 \pm 0.52$ & $9.09 \pm 0.62$ & $0.045(\mathrm{~S})$ \\
\hline TCI (Cal/day) & $650.4 \pm 78.59$ & $679.1 \pm 77.29$ & $622.8 \pm 69.78$ & $0.780(\mathrm{NS})$ \\
\hline$\sum$ FLUD & $2707.6 \pm 415.3$ & $2817.7 \pm 406.5$ & $2601.7 \pm 397.6$ & $0.984(\mathrm{NS})$ \\
\hline GRV (ml) & $144.2 \pm 8.34$ & $146.5 \pm 7.00$ & $142.1 \pm 8.97$ & $0.090(\mathrm{NS})$ \\
\hline SBP (mmHg) & $97.80 \pm 10.24$ & $100.61 \pm 9.52$ & $95.11 \pm 10.21$ & $0.743(\mathrm{NS})$ \\
\hline DBP (mmHg) & $57.63 \pm 7.36$ & $61.27 \pm 5.52$ & $54.14 \pm 7.24$ & $0.531(\mathrm{NS})$ \\
\hline MAP (mmHg) & $68.74 \pm 11.45$ & $71.86 \pm 10.66$ & $65.74 \pm 11.42$ & $0.916(\mathrm{NS})$ \\
\hline HR (bpm) & $101.7 \pm 10.86$ & $98.23 \pm 9.55$ & $105.06 \pm 11.02$ & $0.512(\mathrm{NS})$ \\
\hline SI (bpm/mmHg) & $1.06 \pm 0.23$ & $0.99 \pm 0.18$ & $1.13 \pm 0.25$ & $0.107(\mathrm{NS})$ \\
\hline $\mathrm{mSI}(\mathrm{bpm} / \mathrm{mmHg})$ & $1.55 \pm 0.45$ & $1.41 \pm 0.33$ & $1.68 \pm 0.51$ & $0.017(\mathrm{~S})$ \\
\hline NE rate $(\mu \mathrm{g} / \mathrm{min})$ & $6.66 \pm 6.41$ & $5.86 \pm 5.63$ & $7.42 \pm 7.01$ & $0.000(\mathrm{~S})$ \\
\hline $\mathrm{BG}_{\min }(\mathrm{mg} / \mathrm{dl})$ & $141.2 \pm 15.46$ & $144.39 \pm 12.57$ & $138.11 \pm 17.32$ & $0.084(\mathrm{NS})$ \\
\hline $\mathrm{BG}_{\max }(\mathrm{mg} / \mathrm{dl})$ & $236.5 \pm 21.49$ & $225.98 \pm 9.73$ & $246.64 \pm 24.67$ & $0.000(\mathrm{~S})$ \\
\hline $\mathrm{BG}_{\mathrm{avg}}(\mathrm{mg} / \mathrm{dl})$ & $188.8 \pm 6.53$ & $185 . x 2 \pm 3.61$ & $192.3 \pm 6.80$ & $0.009(\mathrm{~S})$ \\
\hline$\% \mathrm{BG}_{\mathrm{var}}$ & $50.25 \% \pm 16.95 \%$ & $44.14 \% \pm 11.49 \%$ & $56.11 \% \pm 19.19 \%$ & $0.024(\mathrm{~S})$ \\
\hline TDI (IU/day) & $35.52 \pm 11.34$ & $27.25 \pm 6.14$ & $43.62 \pm 15.97$ & $0.000(\mathrm{~S})$ \\
\hline Morphine rate $(\mathrm{mg} / \mathrm{hr})$ & $2.32 \pm 1.77$ & $2.48 \pm 1.74$ & $2.17 \pm 1.79$ & $0.724(\mathrm{NS})$ \\
\hline $\mathrm{PaO}_{2}(\mathrm{mmHg})$ & $61.49 \pm 13.49$ & $72.92 \pm 0.84$ & $50.52 \pm 10.46$ & $0.000(\mathrm{~S})$ \\
\hline $\mathrm{FiO}_{2}$ & $0.53 \pm 0.12$ & $0.42 \pm 0.01$ & $0.63 \pm 0.09$ & $0.000(\mathrm{~S})$ \\
\hline $\mathrm{PaO}_{2} / \mathrm{FiO}_{2}$ ratio & $128.5 \pm 50.34$ & $172.9 \pm 3.98$ & $85.74 \pm 34.93$ & $0.000(\mathrm{~S})$ \\
\hline $\mathrm{PaCO}_{2}(\mathrm{mmHg})$ & $44.91 \pm 11.45$ & $37.90 \pm 0.77$ & $51.92 \pm 9.85$ & $0.000(\mathrm{~S})$ \\
\hline Hospital (LOS) & $17.52 \pm 7.00$ & $11.32 \pm 2.19$ & $23.49 \pm 4.33$ & $0.001(\mathrm{~S})$ \\
\hline \multicolumn{5}{|c|}{$\begin{array}{l}\text { Data are presented as Mean } \pm \text { SD using independent t-test. } \\
\text { Group I: Moderate-severe malnourished hospitalized patients used trophic feeding strategy. } \\
\text { Group II: Moderate-severe malnourished hospitalized patients used nothing by mouth strategy. }\end{array}$} \\
\hline Bw: Body weight. & \multicolumn{2}{|c|}{ H.ALB: Human albumin $20 \%$. } & \multicolumn{2}{|c|}{ SBP: Systolic blood pressure. } \\
\hline BMI: Body mass index. & \multicolumn{2}{|c|}{ BUN: Blood urea nitrogen. } & \multicolumn{2}{|c|}{ DBP: Diastolic blood pressure. } \\
\hline CRP: C-reactive protein. & \multicolumn{2}{|c|}{ TCI: Total calorie input. } & \multicolumn{2}{|c|}{ MAP: Mean arterial pressures. } \\
\hline ALB: Albumin level. & \multicolumn{2}{|c|}{ GRV: Gastric residual volume. } & \multicolumn{2}{|c|}{ HR: Heart rate. } \\
\hline SI: Shock index. & \multicolumn{2}{|c|}{ NE: Norepinephrine. } & \multicolumn{2}{|l|}{ BG: Blood glucose. } \\
\hline mSI: Modified shock index. & \multicolumn{2}{|c|}{ TDI: Total daily insulin. } & \multicolumn{2}{|l|}{ Min: minimum. } \\
\hline 1: baseline at admission. & \multicolumn{2}{|c|}{$\mathrm{PaO}_{2}$ : partial pressure of oxygen. } & \multicolumn{2}{|l|}{ Max: Maximum. } \\
\hline 2: 1 week after admission. & \multicolumn{2}{|c|}{$\mathrm{FiO}_{2}$ : Fractional inspired of oxygen. } & \multicolumn{2}{|l|}{ Avg: Average. } \\
\hline LOS: Length of stay. & \multicolumn{2}{|c|}{$\mathrm{PaCO}_{2}:$ partial pressure of $\mathrm{CO} 2$} & \multicolumn{2}{|l|}{ Var: Variation. } \\
\hline
\end{tabular}

\section{DISCUSSION}

GI impairment often manifests as FI in hospitalized patients, which is associated with malnutrition and poor clinical outcomes [13, 36-38]. In this retrospective analysis, we aimed to explore the impacts of the early trophic administration of a glutamine/arginine enriched ENF to malnourished ward and ICU patients. Accumulating data investigating the individual roles of EN, early EN (EEN), enteral glutamine, and enteral arginine supplementation on major clinicals outcome have been published. 
But this is, to the best of our knowledge, the first study to explore the outcomes of TF using wound healing specialized modular ENF (ArgiMent ${ }^{\mathbb{B}}$ ) compared to not feeding for at least 3 days and up to 7 days before total parenteral nutrition was initiated.

Our primary findings were a significant reduction in all cause 28-day mortality and hospital LOS for patients who received the trophic doses of glutamine/arginine enriched EEN. Levels of daily caloric input have been reported to influence morbidity and mortality in some patients [37-39] but since our studied groups showed no significant differences in BMI nor TCI (which was balanced by the administration of IV dextrose to Group I) the improved survival could not be attributed to the caloric input associated with EN. Thus, we speculated that the improved outcomes were due to the protective effects of EEN on the GI mucosa and its integrity; impeding bacterial translocation. Our methods did not allow us to measure the rates of bacterial translocation, however, considering that: 1) Group II had a higher percentage of patients who exhibited a $\geq 2$-point increase on the SOFA score over one week 2) Group II had higher rates of vasopressor use, we deduced that Group II may have suffered a higher incidence of sepsis. This comes in accordance with reports of increased rates of Enterobacteriaceae sp. translocation in patients with impaired GI tracts suggesting the impaired GI tract as a possible source of sepsis in patients receiving PN [40-41]. The role of EEN in reducing infectious morbidity by maintaining GI barrier function has been well established. For instance, a meta-analysis of 7 RCTs that investigated the effect of EEN as opposed to early PN found EEN to significantly reduce the risk of infectious morbidity; however, no effect on mortality was recorded in that study [13]. When comparing EEN to delayed EN, a meta-analysis of $21 \mathrm{RCT}$ s reported EEN to significantly reduce mortality, which was likely due EEN's role in maintaining components of the GI mucosal [11]. Glutamine deprivation is detrimental to entero- and colonocytes, since glutamine is their main source of energy [30]. Oudemans-van Straaten et al. [33] reported that low plasma glutamine predicted mortality in a cohort of ICU patients. Using glutamine and arginine may have enhanced the speculated protective effects of EN on components of the GI mucosa. A double-blind RCT by Buijs et al. [42] investigated the outcomes of the perioperative administration of arginine-enriched EN versus standard EN to severely malnourished patients with head and neck cancer. They reported significant reductions in both long-term all-cause mortality and disease specific mortality.

Aside from maintaining GI mucosal integrity and immunity, glutamine and arginine have been proven to play a vital role in modulating inflammatory responses and protein metabolism. Glutamine appears to be a key regulator of protein synthesis through its actions on the GCN2 and mTOR pathways. Glutamine also lengthens the half-life of long-lived proteins and stimulates the expression of heat-sock proteins (HSP), HSP-25 and HSP-70, which in turn exert anti-inflammatory effects [30-43] Arginine also enhances protein In a recent review, Mochamat [44] et al. noted that administering perioperative glutamine and arginine in combination with other supplements improved overall survival, reduced infectious morbidity, and increased serum albumin levels in cachectic cancer patients. Our data demonstrated similar outcomes regarding albumin levels. Group I exhibited significantly higher $\% \triangle \mathrm{ALB}$ than Group II despite having significantly higher CRP levels, and receiving significantly lower doses of IV human albumin. However, we observed no significant differences in $\% \Delta B U N$. While these data suggest positive impacts on protein turnover, further studies are needed to confirm these findings.

Although arginine supplementation has been reported to cause nausea, vomiting, and abdominal cramping [44], the glutamine/arginine-enriched formula was well tolerated by our cohort: First, there were no significant differences in the incidence of GI symptoms among the studied groups. RCTs that reported GI symptoms as an adverse effect of arginine used it in combination with omega-3 fatty acids and RNA; however, when used with glutamine, arginine did not appear to cause such symptoms [44]. Second, Group I had a significantly lower rate of prokinetic use, possibly indicating improved GI motility. This comes in agreement with pervious evidence that found both trophic feeding and enteral arginine supplementation to be associated with improved GI motility [14-21]. However, although there were no significant differences in the rates of morphine administration, Group II had significantly higher $\mathrm{BG}_{\text {avg }}$ and rates of norepinephrine use, possibly delaying gastric emptying and increasing their requirement for prokinetics [37]. Further investigations are required to control for these confounders. Furthermore, administering trophic EEN caused no increments in the GRVs of Group I, which remained, on average, below $150 \mathrm{~mL}$ in both groups with no significant differences between them. Regardless 
of the differences between the two groups, GRVs below $150 \mathrm{~mL}$ do not indicate FI and do not warrant withholding EN [10].

In summary, malnourished hypoalbuminemic patients suffering from FI, early trophic administration of glutamine/arginine enriched high protein density ENF was well tolerated and may be associated with increased plasma albumin levels, reduced risk of bacterial translocation and GIT associated sepsis, reduced LOS, and overall 28-day mortality, and hence may be initially considered in moderatesevere wasting ENF's intolerant patients. This study is limited by its retrospective design, and using single-centre data. Nonetheless, our centre is an experienced and high-volume unit, so our data may be useful in other centers. A larger, multisite, and prospective study is needed to control for multiple confounders.

Introducere. Obiectivul studiului a fost de a evalua impactul clinic al administrării dozelor trofice de glutamină şi arginină pe nutriţie enterală (ENF) cu o densitate mare proteică la pacienţii caşectici şi hipoalbuminemici spitalizaţi şi care nu tolerează nutriţia enterală.

Materiale şi metode. A fost realizat un studiu retrospectiv pe pacienţii eligibili internaţi între aprilie 2017 şi aprilie 2019. Pacienţii care au decedat sau care au fost externaţi în mai puţin de o săptămână de la internare sau cei la care datele au fost incomplete au fost excluşi. Au fost analizate modificările albuminei procentual (\% $\% A L B)$ şi proteina $C$ reactivă $(C R P)$ iar raporturile acestora au fost evaluate prin medie şi deviaţie standard şi comparate folosind teste Student-t. Variabilele nominale au fost analizate utilizând testul $\chi^{2}$ test. Au fost evaluate două grupuri de pacienţi - cei care primeau doze trofice ENF şi grupul II care nu primea nutriţie enterală.

Rezultate. Durata spitalizării şi mortalitatea la 28 de zile a fost semnificativ mai mică la pacienţii ENF (11.32 \pm 2.19 zile vs $23.49 \pm 4.33$ zile) şi $(13.13 \%$ vs. $28.16 \%)$. $(\% \triangle A L B)$ a fost semnificativ mai mare la pacienţii ENF $(43.48 \% \pm 7.89 \%$ vs. $33.45 \% \pm 6.18 \%)$.

Concluzii. La pacienţii malnutriţi şi hipoalbuminemici administrarea ENF a fost bine tolerată şi s-a asociat cu creşterea nivelului albuminei şi scăderea duratei de spitalizare şi a ratei mortalităţii şi astfel poate fi luată în considerare pentru aceşti pacienţi.

Correspondence to: Hussien Al-Shebli, M.D, Ph.D, Senior Nephrologist, Postgraduate Diploma in Renal Transplantation Science, Faculty of Health and Life Science, School of Medicine, University of Liverpool, King Hussein Medical Hospital, King Abdullah II St 230, Amman 11733, Jordanian Royal Medical Services.

E-mail: hussienmuhammed74@yahoo.com

Conflict of interest disclosure: The authors declare no conflict of interest.

\section{REFERENCES}

1. YASUDA H, KONDO N, YAMAMOTO R, ASAMIS, ABET, TSUJIMOTO, et al. Monitoring of gastric residual volume during enteral nutrition. Cochrane Database Syst Rev. 2019; 2019 (5).

2. HEYDARI A, ZEYDI A. Is gastric residual volume monitoring in critically ill patients receiving mechanical ventilation an evidence-based practice? Indian J Crit Care Med. 2014; 18(4):259-260.

3. PINILLA JC, SAMPHIRE J, ARNOLD C, LIU L, THIESSEN B. Comparison of gastrointestinal tolerance to two enteral feeding protocols in critically ill patients: A prospective, randomized controlled trial. J Parenter Enter Nutr. 2001; 25(2):81-86.

4. BLASER AR, STARKOPF J, KIRSIMÄGI Ü, DEANE AM. Definition, prevalence, and outcome of feeding intolerance in intensive care: A systematic review and meta-analysis. Acta Anaesthesiol Scand. 2014; 58(8):914-922.

5. WANG K, MCILROY K, PLANK LD, PETROV MS, WINDSOR JA. Prevalence, Outcomes, and Management of Enteral Tube Feeding Intolerance: A Retrospective Cohort Study in a Tertiary Center. J Parenter Enter Nutr. 2017; 41(6):959-967.

6. BLASER AR, POEZE M, MALBRAIN MLNG, et al. Gastrointestinal symptoms during the first week of intensive care are associated with poor outcome: a prospective multicentre study. Intensive Care Med. 2013; 39:899-909. 
7. REINTAM A, PARM P, KITUS R, STARKOPF J, KERN H. Gastrointestinal Failure score in critically ill patients: A prospective observational study. Crit Care. 2008; 12(4):1-8.

8. SHIMIZU K, OGURA H, ASAHARA T, NOMOTO K, MOROTOMI M, NAKAHORI Y, et al. Gastrointestinal dysmotility is associated with altered gut flora and septic mortality in patients with severe systemic inflammatory response syndrome: A preliminary study. Neurogastroenterol Motil. 2011; 23(4):330-336.

9. MENTEC H, DUPONT H, BOCCHETTI M, CANI P, PONCHE F, BLEICHNER G. Upper digestive intolerance during enteral nutrition in critically ill patients: Frequency, risk factors, and complications. Crit Care Med. 2001; 29(10):1955-1961.

10. SINGER P, BLASER AR, BERGER MM, WALEED ALHAZZANI, PHILIP C. CALDER, MICHAEL P. CASAER, et al. ESPEN guideline on clinical nutrition in the intensive care unit. Clin Nutr. 2018; 38(1):48-79.

11. MCCLAVE SA, TAYLOR BE, MARTINDALE RG, MALISSA M WARREN, DEBBIE R. Guidelines for the Provision and Assessment of Nutrition Support Therapy in the Adult Critically Ill Patient: Society of Critical Care Medicine (SCCM) and American Society for Parenteral and Enteral Nutrition (A.S.P.E.N.). J Parenter Enter Nutr. 2016; 40(2):159-211.

12. MCCLAVE SA, DIBAISE JK, MULLIN GE, MARTINDALE RG. ACG clinical guideline: Nutrition therapy in the adult hospitalized patient. Am J Gastroenterol. 2016; 111(3):315-334.

13. REINTAM BLASER A, STARKOPF J, ALHAZZANI W, METTE M BERGER, MICHAEL P CASAER. Early enteral nutrition in critically ill patients: ESICM clinical practice guidelines. Intensive Care Med. 2017; 43(3):380-398.

14. ZHANG Y, GU F, WANG F, ZHANG Y. Effects of early enteral nutrition on the gastrointestinal motility and intestinal mucosal barrier of patients with burn-induced invasive fungal infection. Pakistan J Med Sci. 2016; 32(3):599-603.

15. VEST MT, KOLM P, BOWEN J, JILLIAN T, SHANNON L, MARY SH, et al. Association between enteral feeding, weight status, and mortality in a medical intensive care unit. Am J Crit Care. 2018; 27(2):136-143.

16. PITON G, CAPELLIER G. Biomarkers of gut barrier failure in the ICU. Curr Opin Crit Care. 2016; 22(2):152-160.

17. JABBAR A, CHANG W, DRYDEN GW, MCCLAVE SA. Gut Immunology and the Differential Response to Feeding and Starvation. Nutr Clin Pract. 2003; 18(6):461-482.

18. ZHOU MT, CHEN CS, CHEN BC, ZHANG QY, ANDERSSON R. Acute lung injury and ARDS in acute pancreatitis: Mechanisms and potential intervention. World J Gastroenterol. 2010; 16(17):2094-2099.

19. KUDSK KA. Importance of enteral feeding in maintaining gut integrity. Tech Gastrointest Endosc. 2001; 3(1):2-8.

20. GROOS S, HUNEFELD G, LUCIANO L. Parenteral versus enteral nutrition: morphological changes in human adult intestinal mucosa Title. J Submicrosc Cytol Pathol. 1996; 28(1):61-74.

21. MISHRA S, AGARWAL R, JEEVASANKAR M, DEORARI AK, PAUL VK. Minimal enteral nutrition. Indian J Pediatr. 2008; 75(3):267-269.

22. RICE TW, WHEELER AP, THOMPSON T, et al. EDEN trial: Initial Trophic vs Full Enteral Feeding in Patients with Acute Lung Injury. Jama. 2012; 307(8):795-803.

23. RICE T, MORDAN S, MARGARET H, GORDON B, GORDON J, WHEELER A. A Randomized Trial of Initial Trophic versus Full-Energy Enteral Nutrition in Mechanically Ventilated Patients with Acute Respiratory Failure. Crit Care Med. 2011; 39(5):967-974.

24. FALCÃO DE ARRUDA IS, DE AGUILAR-NASCIMENTO JE. Benefits of early enteral nutrition with glutamine and probiotics in brain injury patients. Clin Sci. 2004; 106(3):287-292.

25. FAN J, MENG Q, GUO G, XIE Y, LI X, XIU Y, et al. Effects of early enteral nutrition supplemented with arginine on intestinal mucosal immunity in severely burned mice. Clin Nutr. 2010; 29(1):124-130.

26. HAMZA N, DARWISH A, O'REILLY DA, DENTON J, SHEEN AJ, DAVID. Perioperative enteral immunonutrition modulates systemic and mucosal immunity and the inflammatory response in patients with periampullary cancer scheduled for pancreaticoduodenectomy: A randomized clinical trial. Pancreas. 2015; 44(1):41-52.

27. GRIFFITHS RD, BONGERS T. Nutrition support for patients in the intensive care unit. Postgrad Med J. 2005; 81(960):629-636.

28. ERSIN S, TUNCYUREK P, ESASSOLAK M, ALKANAT M, BUKE CAQRI. The prophylactic and therapeutic effects of glutamine- and arginine- enriched diets on radiation-induced enteritis in rats. J Surg Res. 2000; 89(2):121-125.

29. HOUDIJK APJ, RIJNSBURGER ER, JANSEN J, WESDORP R IC, JEFFERY K. Randomised trial of glutamine-enriched enterai nutrition on infectious morbidity in patients with multiple trauma. Lancet. 1998;352(9130):772-776.

30. SALEM YA, LABIB HA, ALGENDY MAS. Intravenous glutamine supplementation improves gut mucosal function in burn patients: a randomized controlled trial. Ain-Shams J Anaesthesiol. 2017; 10:60-67.

31. ZIEGLER TR, EVANS ME, FERNÁNDEZ-ESTÍVARIZ C, JONES DP. Trophic and Cytoprotective Nutrition for Intestinal Adaptation, Mucosal Repair, and Barrier Function. Annu Rev Nutr. 2003; 23(1):229-261.

32. ZHU HL, LIU YL, XIE XL, HUANG JJ, HOU YQ. Effect of l-arginine on intestinal mucosal immune barrier function in weaned pigs after Escherichia coli LPS challenge. Innate Immun. 2013; 19(3):242-252.

33. OUDEMANS-VAN STRAATEN HM, BOSMAN R, TREKES M, VAN DER SPOEL H, ZANDSTA D. Plasma glutamine depletion and patient outcome in acute ICU admissions. Intensive Care Med. 2001; 27(1):84-90.

34. KREYMANN KG, BERGER MM, DEUTZ NEP, HIESMAVR M, JOLLIET P, KAZANDIIEV G, et al. ESPEN Guidelines on Enteral Nutrition: Intensive care. Clin Nutr. 2006;25(2):210-223.

35. CUI XL, IWASA M, IWASA Y, OHMORI Y, YAMAMOTO AK, HIRONORI. Effects of dietary arginine supplementation on protein turnover and tissue protein synthesis in scald-burn rats. Nutrition. 1999; 15(7-8):563-569.

36. LEW CCH, YANDELL R, FRASER RJL, CHUA AP, CHONG MFF, MILLER M. Association between Malnutrition and Clinical Outcomes in the Intensive Care Unit: A Systematic Review. J Parenter Enter Nutr. 2017; 41(5):744-758.

37. DEANE A, CHAPMAN MJ, FRASER RJ, BRYANT LK, BURGSTAD C, NGUYEN NQ. Mechanisms underlying feed intolerance in the critically ill: Implications for treatment. World J Gastroenterol. 2007; 13(29):3909-3917.

38. IKRAM S, HUSSAIN E, ZUBAIRI ABS. Nutrition in intensive care in adults review of the literature and development of evidence based feeding protocols. J Pak Med Assoc. 2016; 66(9):1154-1164. 
39. BUFARAH MNB, COSTA NA, LOSILLA MPRP, REIS NSC, SILVA MZC, BALBI AL, PONCE D. Low caloric and protein intake is associated with mortality in patients with acute kidney injury. Clin Nutr ESPEN. 2018; 24:66-70.

40. EARLEY ZM, AKHTAR S, GREEN SJ, NAQIB A, KHAN O, ABIGAIL R. Burn injury alters the intestinal microbiome and increases gut permeability and bacterial translocation. PLoS One. 2015; 10(7):1-16.

41. TIAN J, HAO L, CHANDRA P, JONES DP, WILLAMS IR, GEWIRTZ AT. Dietary glutamine and oral antibiotics each improve indexes of gut barrier function in rat short bowel syndrome. Am J Physiol - Gastrointest Liver Physiol. 2009; 296(2):348-355.

42. BUIJS N, VAN BOKHORST-DE VAN DER SCHUEREN MAE, LANGIUS JAE, RENE C. Perioperative arginine-supplemented nutrition in malnourished patients with head and neck cancer improves long-term survival. Am J Clin Nutr. 2010; 92(5):1151-1156.

43. BOUKHETTALA N, CLAEYSSENS S, BENSIFI M, MAURER B, ABED JULIETTE, ALAIN. Effects of essential amino acids or glutamine deprivation on intestinal permeability and protein synthesis in HCT-8 cells: Involvement of GCN2 and mTOR pathways. Amino Acids. 2012; 42(1):375-383.

44. MOCHAMAT, CUHLS H, MARINOVA M, KAASA ST, STIEBER CHRIS, CONRAD R, LUKAS. A systematic review on the role of vitamins, minerals, proteins, and other supplements for the treatment of cachexia in cancer: a European Palliative Care Research Centre cachexia project. J Cachexia Sarcopenia Muscle. 2017; 8(1):25-39.

Received $3^{\text {rd }}$ March 2020 